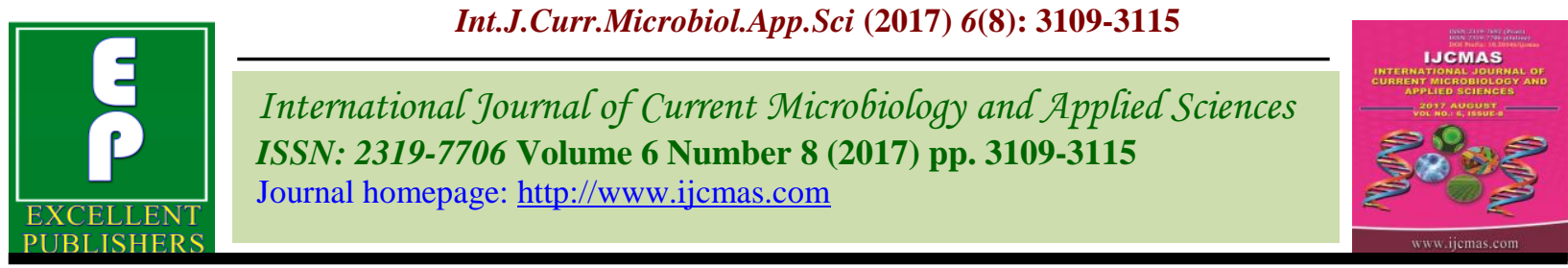

Original Research Article

https://doi.org/10.20546/ijcmas.2017.608.372

\title{
Weed Indices as Influenced by Propaquizafop and Imazethapyr Mixture in Soybean
}

\author{
Shyam Lal*, M.L. Kewat and Tarun Suryavanshi \\ Department of Agronomy, college of Agriculture, JNKVV, Jabalpur \\ (Madhya Pradesh) 482004, India \\ *Corresponding author
}

\section{A B S T R A C T}

Keywords

Soybean, Weed indices, Growth parameter, Yield attributes, Yield.

Article Info

Accepted:

26 June 2017

Available Online:

10 August 2017
A field experiment was conducted during kharif seasons of 2013 and 2014 at Livestock Farm, JNKVV, Jabalpur (M.P.). Eight treatments comprising of four doses of propaquizafop + imazethapyr mixture $(47+66,50+70,53+74$ and $56+78$ $\mathrm{g} / \mathrm{ha})$, alone application of propaquizafop (75 g/ha) and imazethapyr (100 g/ha), hand weeding twice (20 and 40 DAS) including weedy check were laidout in randomized block design with three replications. Post-emergence application of propaquizafop + imazethapyr mixture at $53+74$ and $56+78 \mathrm{~g} /$ ha at 30 days after application effectively curbed the density and dry weight of grasses, sedges and broad-leaved weeds and attained superior values of weed indices, yield attributing traits, seed and haulm yields comparable to hand weeding twice (20 and 40 DAS). But found superior over application of mixture at lower rates $(47+66$ and $50+70$ $\mathrm{g} / \mathrm{ha})$, alone application of propaquizafop (75 g/ha) and imazethapyr (100 g/ha) which attained the inferior values of weed indices due to poor weed control.

\section{Introduction}

Soybean (Glycine max) is one of the most important commercial crops in India. The crop is called "Golden Bean" or "Miracle crop" of the $21^{\text {st }}$ century because of its multiple uses. It has the highest protein content (40-42\%), 20 per cent oil, rich in lycine and vitamins $\mathrm{A}, \mathrm{B}$ and $\mathrm{D}$, also rich source of minerals and essential amino acids (Jadhav, 2014).

Several herbicides viz., Pendimethalin, Fluchloralin, Metalochor and Alachlor etc. were in use for controlling weeds associated in soybean, but these have not been found much effective in controlling all sort of weeds. Henceforth, it is imperative to evaluate the efficacy of suitable postemergence herbicides alone and in mixture for effective control of dominant and diversified weed flora in soybean fields. Presently, imazethapyr is reportedly very effective post emergence herbicide for controlling some grassy and broad leaf weeds in soybean but its efficacy has not been tested with propaquizafop for wide spectrum weed control in soybean in different parts of the country including Jabalpur.

Keeping the above facts in view, the present investigation was carried out to adjudge the effect of herbicidal mixture on weed indices, yield attributes and yield of soybean. 


\section{Materials and Methods}

The field experiment was conducted at Livestock Farm, Department of Agronomy, JNKVV, Jabalpur during kharif season of 2013 and 2014 in order to test the efficacy of propaquizafop and imazethapyr mixture against mixed weed flora in soybean. The climate of this region is sub-humid and tropical. The total rainfall received during kharif season (June to October) for the year 2013 and 2014 was $2435.20 \mathrm{~mm}$ and, respectively.

The soil of experimental site was clay in texture with $\mathrm{pH} 7.2$, medium in organic carbon $0.65 \%$, available nitrogen $(351 \mathrm{~kg} / \mathrm{ha})$, phosphorus $(16.5 \mathrm{~kg} / \mathrm{ha})$ but high in potassium $(339.7 \mathrm{~kg} / \mathrm{ha})$. Eight treatments comprising of four rates of propaquizafop + imazethapyr mixture $(47+66,50+70,53+74$ and $56+78 \mathrm{~g} / \mathrm{ha}$ ), alone application of propaquizafop (75 g/ha) and imazethapyr (100 g/ha), hand weeding twice (20 and 40 DAS) including weedy check, were laidout in randomized block design with three replications.

Soybean variety JS 97-52 was grown on 3 July with row spacing of $45 \mathrm{~cm}$ and a plant spacing of nearly $5 \mathrm{~cm}$ during both the years. The recommended dose of fertilizers for soybean was $20 \mathrm{~kg} \mathrm{~N}, 60 \mathrm{~kg} \mathrm{P}_{2} \mathrm{O}_{5}$ and $20 \mathrm{~kg}$ $\mathrm{K}_{2} \mathrm{O} /$ ha. The whole quantity of $\mathrm{N}, \mathrm{P}$, and $\mathrm{K}$ was applied through urea, single super phosphate and muriate of potash at the time of sowing of soybean. Total weed population $/ \mathrm{m}^{2}$ was recorded at 30 DAA under each treatment with the help of $0.25 \mathrm{~m}^{2}$ quadrat. Weed population was recorded in weedy check to work out the relative density of weeds. The weed dry matter was also recorded at 30 DAA. Data on weed density and weed biomass were transformed using square root transformation. Weed indices were computed using the standard procedure as following details:

\section{Herbicide efficiency index (Krishnamurthy et al., 1975)}

This index indicates the potential of herbicides for killing weeds and their phytotoxicity on the crop and was computed using the following formula:

$\mathrm{HEI}=\frac{\frac{(\mathrm{Yt}-\mathrm{Yc})}{\mathrm{Yt}} \times 100}{\frac{\mathrm{WDMt}}{\mathrm{WDMc}} \times 100}$

Where,

Yt- crop yield from treated plot

Yc- crop yield from weedy check plot

WDMt-weed dry matter in treated plot

WDMc-weed dry matter in weedy check plot

WPI $=\frac{\text { Weed population in control plot }}{\text { Weed population in treated plot }} \times$

Weed dry weight in treated plot

Weed dry weight in control plot

\section{Weed persistence index (WPI)}

This index indicates the resistance in weeds against the tested treatments and confirms the effectiveness of the selected herbicides, and the same was computed using the given formula as suggested by Mishra and Mishra, 1997:

\section{Crop resistance index (CRI) (Mishra and Mishra, 1997)}

It gives the relationship between a proportionate increase in crop biomass and a proportionate decrease in weed biomass in the treated plots. 
It was computed using the formulas given by Mishra and Mishra, 1997:

Crop dry weight in treated plot
Crop dry weight in control plot
Weed dry weight in control plot

Weed dry weight in treated plot

Weed control efficiency (WCE)

$\mathrm{WI}(\%)=\frac{\mathrm{X}-\mathrm{Y}}{\mathrm{X}} \times 100$

Weed control efficiency measures the efficiency of any weed control treatment in comparison to weedy treatment. To adjudge the efficiency of weed control treatments, weed control efficiency (WCE) was calculated (Mani et al., 1973: Das, 2008) as follows:

$\operatorname{WCE}(\%)=\frac{\mathrm{WP}_{\mathrm{C}}-\mathrm{WP}_{\mathrm{T}}}{\mathrm{WPC}} \times 100$

Where, $\mathrm{WP}_{\mathrm{C}}$ is the weed population $\left(\mathrm{no} / \mathrm{m}^{2}\right)$ in unweeded plot and $\mathrm{WP}_{\mathrm{T}}$ is the weed population $\left(\mathrm{no} / \mathrm{m}^{2}\right)$ in treated plot.

\section{Weed control index (WCI)}

To compare the different treatments of weed control on the basis of dry weight, weed control index (WCI) was calculated as follows (Mani et al., 1973 and Das, 2008). It indicates the per cent reduction in the dry weight in treated plots compared to weedy plots.

\section{DWC - DWT}

Weed control efficiency

(WCI), \% = $\times 100$
Where,

$\mathrm{WCE}=$ Weed control efficiency

DWC $=$ Dry weight of weeds in control plots

DWT $=$ Dry weight of weeds in treated plots

\section{Weed index (WI)}

Weed index is defined as the per cent reduction in the seed yield under a particular treatment due to the presence of weeds in comparison to the seed yield obtained in weed free plot as suggested by Gill and Kumar (1969).

It is expressed in percentage and was determined with the help of following formula:

$\mathrm{WI}(\%)=\frac{\mathrm{X}-\mathrm{Y}}{\mathrm{X}} \times 100$

Where,

$\mathrm{WI}=$ Weed index

$\mathrm{X}=$ Seed yield from weed free plot (hand weeding)

$\mathrm{Y}=$ Seed yield from the treated plot for which weed index is to be worked out

\section{Weed management index (WMI)}

This index is the ratio of yield increase over the control because of weed management and percent control of weeds by the respective treatment it was computed as per following formula:

Per cent crop yield increase over control $\mathrm{WMI}=$

Per cent control of weeds 


\section{Results and Discussion}

\section{Weed density and biomass}

The total weed density and biomass differed significantly at 30 DAA due to weed control treatments (Table 1). The total density and biomass of weeds was maximum $\left(15.28 / \mathrm{m}^{2}\right.$ and $21.61 \mathrm{~g} / \mathrm{m}^{2}$ ) under weedy check plots at 30 DAA, where weeds were not controlled by any means.

Post emergence application of propaquizafop + imazethapyr mixture at the lowest dose $(47+66 \mathrm{~g} / \mathrm{ha})$ caused appreciable reduction in the density and biomass of weeds over weedy check plots.

However, the efficacy of propaquizafop + imazethapyr mixture was further improved with the corresponding increase in the rates of application from $47+66$ to $53+74 \mathrm{~g} / \mathrm{ha}$ or higher rates $(56+78 \mathrm{~g} / \mathrm{ha})$ and proved superior over other herbicidal treatments.

But, hand weeding twice excelled to all the herbicidal treatments as it curbed the density and biomass of grassy, sedge and dicot weeds to a larger extent $\left(3.46 / \mathrm{m}^{2}\right.$ and $\left.1.78 \mathrm{~g} / \mathrm{m}^{2}\right)$.

The presence of propaquizafop+ imazethapyr mixture in non-lethal concentration at the site of action could be the reason for poor activity of propaquizafop + imazethapyr mixture when applied at the lowest dose $(47+66 \mathrm{~g} / \mathrm{ha})$ but the reverse was true when it was applied at higher rates.

On the other hand, check herbicides propaquizafop at $75 \mathrm{~g} / \mathrm{ha}$ as post emergence caused more reduction in the density and dry weight of grassy weeds only and similarly imazethapyr at $100 \mathrm{~g} / \mathrm{ha}$ as post emergence caused some reduction in the density of both grassy and broad leaved weeds as compared to weedy check plots. However, hand weeding twice at 20 and 40 DAS reduced the density including dry weight of weeds to the maximum extent over herbicidal treatments due to elimination of all sort of weeds during the course of hand weeding (Das, 2008).

\section{Yield attributes}

Excellent growth and development of soybean plants under weed free environment during critical period of crop growth might have resulted in superior yield attributes under aforesaid herbicidal treatments including hand weeding treatment as compared to weedy check, which had severe weed competition from early growth stages and ultimately resulted into most inferior yield attributes.

The perusal of data (Table 2) indicated that all the plots receiving propaquizafop+ imazethapyr mixture at different rates $(47+66$, $50+70,53+74$ and $56+78 \mathrm{~g} / \mathrm{ha})$ and alone application of propaquizafop (75 g/ha) and imazethapyr (100 g/ha) including hand weeding twice, did not cause significant variation on number of seeds per pod and seed index of soybean as both characters are governed by genetic factor.

However, post-emergence application of propaquizafop + imazethapyr mixture at $53+74 \mathrm{~g} / \mathrm{ha}$ or higher rates $(56+78 \mathrm{~g} / \mathrm{ha})$ as post emergence produced significantly more number of pods per plant compared to lower rates $(47+66$ and $50+70 \mathrm{~g} / \mathrm{ha})$ and alone application of propaquizafop $75 \mathrm{~g} / \mathrm{ha}$ and imazethapyr $100 \mathrm{~g} / \mathrm{ha}$, on account of reduction in weed growth to the level of satisfaction coupled with no inhibitory effects on soybean plants and found at par to hand weeding twice (20 and 40 DAS).

Whereas, poor weed control under latter treatments might have produced inferior yield attributes particularly pods per plant due to poor control of weeds. 
Table.1 Weed density and weed dry weight at 30 days after application of herbicidal treatments (mean of two seasons)

\begin{tabular}{|c|c|c|c|c|c|c|c|c|}
\hline \multirow{2}{*}{ Treatment } & \multicolumn{4}{|c|}{ Weed density $\left(\mathrm{no} / \mathrm{m}^{2}\right)$} & \multicolumn{4}{|c|}{ Weed dry weight $\left(\mathrm{g} / \mathrm{m}^{2}\right)$} \\
\hline & Grass & Sedge & Broad leaf & Total & Grass & Sedge & Broad leaf & Total \\
\hline $\mathrm{T}_{1}$ Propaquizafop+Imazethapyr $(47+66 \mathrm{~g} / \mathrm{ha})$ & $\begin{array}{c}67.7 \\
(\mathbf{8 . 7 3})\end{array}$ & $\begin{array}{l}15.67 \\
(4.46)\end{array}$ & $\begin{array}{l}23.33 \\
\mathbf{( 5 . 3 3 )}\end{array}$ & $\begin{array}{l}106.67 \\
(\mathbf{1 0 . 8 3 )}\end{array}$ & $\begin{array}{l}122.23 \\
\mathbf{( 1 1 . 5 6 )}\end{array}$ & $\begin{array}{l}34.73 \\
(6.39)\end{array}$ & $\begin{array}{l}25.12 \\
(\mathbf{5 . 5 1 )}\end{array}$ & $\begin{array}{l}182.08 \\
\mathbf{( 1 3 . 9 9 )}\end{array}$ \\
\hline $\mathrm{T}_{2}$ Propaquizafop+Imazethapyr $(50+70 \mathrm{~g} / \mathrm{ha})$ & $\begin{array}{c}59.7 \\
(\mathbf{8 . 2 2})\end{array}$ & $\begin{array}{l}13.33 \\
\mathbf{( 4 . 1 5 )}\end{array}$ & $\begin{array}{l}18.33 \\
\mathbf{( 4 . 7 8 )}\end{array}$ & $\begin{array}{c}91.32 \\
(\mathbf{1 0 . 0 6})\end{array}$ & $\begin{array}{c}106.3 \\
(\mathbf{1 0 . 8 1 )}\end{array}$ & $\begin{array}{c}29.6 \\
(\mathbf{5 . 9 4 )}\end{array}$ & $\begin{array}{l}18.78 \\
(\mathbf{4 . 8 3})\end{array}$ & $\begin{array}{l}154.68 \\
\mathbf{( 1 2 . 9 4 )}\end{array}$ \\
\hline $\mathrm{T}_{3}$ Propaquizafop+Imazethapyr $(53+74 \mathrm{~g} / \mathrm{ha})$ & $\begin{array}{c}44.3 \\
(7.16)\end{array}$ & $\begin{array}{c}9.33 \\
(\mathbf{3 . 5 5})\end{array}$ & $\begin{array}{l}13.67 \\
\mathbf{( 4 . 2 0 )}\end{array}$ & $\begin{array}{l}67.34 \\
(\mathbf{8 . 7 1})\end{array}$ & $\begin{array}{l}79.57 \\
(\mathbf{9 . 4 2 )}\end{array}$ & $\begin{array}{l}20.35 \\
\mathbf{( 5 . 0 1 )}\end{array}$ & $\begin{array}{c}12.1 \\
(\mathbf{3 . 9 8})\end{array}$ & $\begin{array}{l}112.02 \\
\mathbf{( 1 1 . 0 8 )}\end{array}$ \\
\hline $\mathrm{T}_{4}$ Propaquizafop+Imazethapyr $(56+78 \mathrm{~g} / \mathrm{ha})$ & $\begin{array}{c}36.7 \\
(\mathbf{6 . 5 5})\end{array}$ & $\begin{array}{c}7.33 \\
\mathbf{( 3 . 2 1 )}\end{array}$ & $\begin{array}{c}10 \\
(\mathbf{3 . 6 6})\end{array}$ & $\begin{array}{l}53.99 \\
\mathbf{( 7 . 8 5 )}\end{array}$ & $\begin{array}{l}62.87 \\
(\mathbf{8 . 4 3}) \\
\end{array}$ & $\begin{array}{l}15.55 \\
\mathbf{( 4 . 4 4 )}\end{array}$ & $\begin{array}{c}10.9 \\
(\mathbf{3 . 8 0})\end{array}$ & $\begin{array}{r}89.32 \\
(\mathbf{9 . 9 5})\end{array}$ \\
\hline $\mathrm{T}_{5}$ Propaquizafop $(75 \mathrm{~g} / \mathrm{ha})$ & $\begin{array}{c}61.3 \\
(\mathbf{8 . 3 3}) \\
\end{array}$ & $\begin{array}{l}18.33 \\
\mathbf{( 4 . 7 8 )} \\
\end{array}$ & $\begin{array}{c}30 \\
\mathbf{( 5 . 9 8 )} \\
\end{array}$ & $\begin{array}{r}109.66 \\
\mathbf{( 1 0 . 9 7 )}\end{array}$ & $\begin{array}{r}117.18 \\
\mathbf{( 1 1 . 3 2 )}\end{array}$ & $\begin{array}{l}43.03 \\
\mathbf{( 7 . 0 6 )}\end{array}$ & $\begin{array}{l}39.15 \\
(\mathbf{6 . 7 6}) \\
\end{array}$ & $\begin{array}{r}199.36 \\
\mathbf{( 1 4 . 6 2 )}\end{array}$ \\
\hline $\mathrm{T}_{6}$ Imazethapyr (100 g/ha) & $\begin{array}{c}76.3 \\
(\mathbf{9 . 2 4})\end{array}$ & $\begin{array}{l}15.637 \\
\mathbf{( 4 . 4 5 )}\end{array}$ & $\begin{array}{l}15.67 \\
\mathbf{( 4 . 4 6 )}\end{array}$ & $\begin{array}{c}107.637 \\
(\mathbf{1 0 . 8 7})\end{array}$ & $\begin{array}{l}131.92 \\
(\mathbf{1 1 . 9 9 )}\end{array}$ & $\begin{array}{l}35.39 \\
(\mathbf{6 . 4 5})\end{array}$ & $\begin{array}{l}15.11 \\
\mathbf{( 4 . 3 9 )}\end{array}$ & $\begin{array}{r}182.42 \\
\mathbf{( 1 4 . 0 1 )}\end{array}$ \\
\hline $\mathrm{T}_{7}$ Hand weeding $(20 \& 40 \mathrm{DAS})$ & $\begin{array}{c}6.0 \\
(\mathbf{2 . 9 5}) \\
\end{array}$ & $\begin{array}{c}3.33 \\
(\mathbf{2 . 3 2}) \\
\end{array}$ & $\begin{array}{c}2.67 \\
(\mathbf{2 . 1 3}) \\
\end{array}$ & $\begin{array}{r}11.99 \\
\mathbf{( 3 . 9 6 )}\end{array}$ & $\begin{array}{c}1.53 \\
\mathbf{( 1 . 7 4 )}\end{array}$ & $\begin{array}{c}0.83 \\
(\mathbf{1 . 4 1})\end{array}$ & $\begin{array}{c}0.3 \\
(\mathbf{1 . 0 5}) \\
\end{array}$ & $\begin{array}{c}2.66 \\
\mathbf{( 2 . 1 3 )}\end{array}$ \\
\hline $\mathrm{T}_{8}$ Weedy check & $\begin{array}{c}169.7 \\
\mathbf{( 1 3 . 5 3 )}\end{array}$ & $\begin{array}{l}25.33 \\
\mathbf{( 5 . 5 3 )} \\
\end{array}$ & $\begin{array}{l}38.33 \\
(\mathbf{6 . 6 9 )} \\
\end{array}$ & $\begin{array}{l}233.33 \\
(\mathbf{1 5 . 7 8 )}\end{array}$ & $\begin{array}{l}351.05 \\
\mathbf{( 1 9 . 2 4 )}\end{array}$ & $\begin{array}{l}61.61 \\
(\mathbf{8 . 3 5}) \\
\end{array}$ & $\begin{array}{l}53.85 \\
\mathbf{( 7 . 8 4 )} \\
\end{array}$ & $\begin{array}{l}466.51 \\
\mathbf{( 2 2 . 1 0 )}\end{array}$ \\
\hline SE.m \pm & 0.09 & 0.03 & 0.07 & 0.09 & 0.08 & 0.08 & 0.07 & 0.18 \\
\hline $\operatorname{LSD}(\mathrm{P}=0.05)$ & 0.27 & 0.10 & 0.22 & 0.27 & 0.24 & 0.25 & 0.22 & 0.55 \\
\hline
\end{tabular}

Table.2 Influence of weed control treatments on yield attributes and yield of soybean (mean of two seasons)

\begin{tabular}{|c|c|c|c|c|c|}
\hline Treatment & Pods/ plant & Seeds/ pod & Seed index (g) & $\begin{array}{c}\text { Seed yield } \\
\text { (t/ha) }\end{array}$ & $\begin{array}{c}\text { Haulm yield } \\
\text { (t/ha) }\end{array}$ \\
\hline $\mathrm{T}_{1}$ Propaquizafop+Imazethapyr $(47+66 \mathrm{~g} / \mathrm{ha})$ & 28.42 & 2.00 & 6.74 & 1.52 & 3.31 \\
\hline $\mathrm{T}_{2}$ Propaquizafop+Imazethapyr $(50+70 \mathrm{~g} / \mathrm{ha})$ & 30.62 & 2.00 & 6.77 & 1.65 & 3.61 \\
\hline $\mathrm{T}_{3}$ Propaquizafop+Imazethapyr $(53+74 \mathrm{~g} / \mathrm{ha})$ & 38.95 & 2.00 & 6.90 & 2.16 & 4.29 \\
\hline $\mathrm{T}_{4}$ Propaquizafop+Imazethapyr $(56+78 \mathrm{~g} / \mathrm{ha})$ & 39.47 & 2.00 & 6.90 & 2.18 & 4.31 \\
\hline $\mathrm{T}_{5}$ Propaquizafop $(75 \mathrm{~g} / \mathrm{ha})$ & 25.11 & 2.00 & 6.70 & 1.35 & 3.09 \\
\hline $\mathrm{T}_{6}$ Imazethapyr $(100 \mathrm{~g} / \mathrm{ha})$ & 29.37 & 2.00 & 6.73 & 1.59 & 3.21 \\
\hline $\mathrm{T}_{7}$ Hand weeding $(20 \& 40 \mathrm{DAS})$ & 40.00 & 2.00 & 6.90 & 2.21 & 4.31 \\
\hline $\mathrm{T}_{8}$ Weedy check & 19.82 & 2.00 & 6.60 & 1.05 & 2.88 \\
\hline $\mathrm{SEm} \pm$ & 0.82 & 0.55 & 0.07 & 0.04 & 0.12 \\
\hline $\operatorname{LSD}(\mathrm{P}=0.05)$ & 2.46 & $\mathrm{NS}$ & $\mathrm{NS}$ & 0.13 & 0.37 \\
\hline
\end{tabular}


Table. 3 Effects of weed control treatments on various weed indices in soybean

\begin{tabular}{|l|c|c|c|c|c|c|c|}
\hline \multicolumn{1}{|c|}{ Treatment } & WCE & WCI & WI & HEI & CRI & WPI & WMI \\
\hline $\mathrm{T}_{1}$ Propaquizafop+Imazethapyr $(47+66 \mathrm{~g} / \mathrm{ha})$ & 54.28 & 60.96 & 31.22 & 0.80 & 3.15 & 0.85 & 0.74 \\
\hline $\mathrm{T}_{2}$ Propaquizafop+Imazethapyr $(50+70 \mathrm{~g} / \mathrm{ha})$ & 60.86 & 66.83 & 25.33 & 1.11 & 4.05 & 0.85 & 0.87 \\
\hline $\mathrm{T}_{3}$ Propaquizafop+Imazethapyr $(53+74 \mathrm{~g} / \mathrm{ha})$ & 71.14 & 75.35 & 2.26 & 2.15 & 6.84 & 0.83 & 1.41 \\
\hline $\mathrm{T}_{4}$ Propaquizafop+Imazethapyr $(56+78 \mathrm{~g} / \mathrm{ha})$ & 76.86 & 80.77 & 1.35 & 2.71 & 8.64 & 0.83 & 1.34 \\
\hline $\mathrm{T}_{5}$ Propaquizafop $(75 \mathrm{~g} / \mathrm{ha})$ & 53.00 & 57.44 & 38.91 & 0.52 & 2.65 & 0.91 & 0.50 \\
\hline $\mathrm{T}_{6}$ Imazethapyr $(100 \mathrm{~g} / \mathrm{ha})$ & 53.86 & 61.41 & 28.05 & 0.87 & 3.13 & 0.85 & 0.84 \\
\hline $\mathrm{T}_{7}$ Hand weeding(20 \& 40 DAS) & 94.86 & 99.42 & 0.00 & - & - & 0.11 & 1.12 \\
\hline $\mathrm{T}_{8}$ Weedy check & 0.00 & 0.00 & 52.48 & - & - & - & \\
\hline
\end{tabular}

$\mathrm{WCE}=$ weed control efficiency, $\mathrm{WCI}=$ weed control index, $\mathrm{WI}=$ weed index, $\mathrm{HEI}=$ herbicide efficiency index, $\mathrm{CRI}=$ crop resistance index, $\mathrm{WPI}=$ weed persistence index, $\mathrm{WMI}=$ weed management index .

\section{Soybean seed and haulm yields}

The seed and haulm yields were minimum (10.46 and $28.75 \mathrm{q} / \mathrm{ha})$ in weedy check plots due to severe competitional stress from crop establishment up to the end of critical period of crop growth, leading to poor growth parameters and yield attributing traits and finally resulted into minimum seed yield (Table 2).

But, it was increased marginally when propaquizafop + imazethapyr mixture was applied at lower rates being the higher when propaquizafop + imazethapyr was applied in combination at $53+74 \mathrm{~g} / \mathrm{ha}$ or higher rate $(56$ $+78 \mathrm{~g} / \mathrm{ha}$ ) being comparable to hand weeding twice (20 and 40 DAS) and proved significantly superior over herbicidal mixture applied at lower rates $(47+66$ and $50+70 \mathrm{~g} / \mathrm{ha})$ and alone application of propaquizafop (75 $\mathrm{g} / \mathrm{ha})$ and imazethapyr (100 g/ha).

The plots receiving propaquizafop + imazethapyr mixture at $53+74$ and $56+78$ $\mathrm{g} / \mathrm{ha}$ including hand weeded plots attained lush growth due to elimination of most of the weeds besides better availability of space, moisture nutrients and light which in turn had superior yield attributes and consequently the higher yields.

Whereas, reverse was true for other herbicidal treatments.
Effects of weed control treatments on various agronomic indices in soybean

The values of weed indices like weed control efficiency (WCE), weed control index (WCI), herbicide efficiency index (HEI), crop resistance index (CRI), weed management index (WMI), weed index (WI) and weed persistency index(WPI) were inferior in plots receiving no any weed control throughout the growing season (Table 3). But combined application of propaquizafop + imazethapyr at $53+74$ and $56+78 \mathrm{~g} / \mathrm{ha}$ recorded superior values of WCE, WCI, HEI, CRI, WMI, WI and WPI to that of hand weeding twice (20 and 40 DAS) and these proved better than combined application of propaquizafop + imazethapyr applied at lower rates $(47+66$ and $50+70 \mathrm{~g} / \mathrm{ha}$ ), alone application of propaquizafop (75 $\mathrm{g} / \mathrm{ha}$ ) and imazethapyr $(100 \mathrm{~g} / \mathrm{ha})$. Better control of weeds under combined application of propaquizafop + imazethapyr at $53+74 \mathrm{~g} / \mathrm{ha}$ or higher rate (56 $+78 \mathrm{~g} / \mathrm{ha}$ ) including hand weeding plots could be assigned the reason for superior weed indices. But identically reverse was true in case of rest of the herbicidal treatments. Similar results have also been reportedly Krishnamurthy et al., 1975.

\section{References}

Das, T. K. (2008). Weed science: basics and applications. $1^{\text {st }}$ Eddition: Jain Brothers 
Publishers, New Delhi, p 901.

Gill, G.S. and Kumar, V. (1969). Weed index, a new method for reporting weed control trials. Indian Journal of Agronomy 14(2): 96-98.

Jadhav, A. S. (2014). Production potential of soybean-wheat cropping system through weed management. Indian Journal of Weed Science 46(2): 190-191.

Krishnamurthy, K., Raju, B. G., Raghunath, G., Jagnath, M. K. and Prasad, T. V. R.
(1975). Herbicide efficiency index in sorghum. Indian Journal of Weed Science, 7 (2): 75-79.

Mani, V.S., Malla, M.L., Gautam, K.C. and Das, B. (1973). Weed killing chemical in potato cultivation. PANS 23 (8): 1718.

Misra, M., Misra, A., (1997). Estimation of IPM index in Jute: a new approach. Indian Journal of Weed Science, 29, 39-42.

\section{How to cite this article:}

Shyam Lal, M.L. Kewat and Tarun Suryavanshi. 2017. Weed Indices as Influenced by Propaquizafop and Imazethapyr Mixture in Soybean. Int.J.Curr.Microbiol.App.Sci. 6(8): 31093115. doi: https://doi.org/10.20546/ijcmas.2017.608.372 